\title{
Need Analysis on English for Computer and Technique
}

\author{
Hafizah Rifiyanti ${ }^{1 *}$, Dyah Utami Dewi ${ }^{2}$ \\ ${ }^{1}$ Ilmu Komputer, Institut Bisnis dan Informatika Kosgoro 1957, Indonesia \\ ${ }^{2}$ Manajemen, Institut Bisnis dan Informatika Kosgoro 1957, Indonesia \\ *havizarifiyanti@gmail.com
}

\begin{abstract}
Practice is as important as the theory in learning a language. A recommended syllabus is needed to use in the institution according to the need of the learners as well. This esearch aims to analyze the necessities, the lacks and wants of the learners in the English for Computer and Technique course. The research method is descriptive with a qualitative model. The survey research using a series of questionnaires and was distributed to 32 respondents from the informatics study program. In collecting the data, the researcher applied questionnaire for the students as the instrument of the research. The results of the needs analysis concluded that students need English to improve their speaking, listening, reading, and writing. material that per the field of science, namely computer science, becomes more interesting and strongly supports the knowledge being studied. The implementation of this research is to prepare an Semester Learning Plan in accordance to the student's needs and to develop lecturer competence as well as technology and information progress.
\end{abstract}

Keywords: english for computer and technique, english for specific purposes, need analysis.

Identitas Artikel:

Rifiyanti, H., Dewi, D. U. (2022). Need Analysis on English for Computer and Technique. Jurnal Ilmu Pendidikan (JIP) STKIP Kusuma Negara, 13(2), 135-143.

\section{INTRODUCTION}

The change in educational orientation at the high level not only produces intelligent graduates but the most important are graduates who can apply their knowledge in society, the world of work, and their daily lives as well. While competition in the workplace today demands universities also to produce the best graduates with the competencies needed in the world of work so that this affects the concept of curriculum and syllabus that will be applied to students so that the achievements produced by students can meet the demands of every field of science they learn. The direct application of the knowledge learned by students during their studies will make the knowledge they learn not wasted. One of the competencies that are currently mandatory for every university graduate is excellent English language competence, therefore English is a compulsory subject in every university. In this regard, the reference to the materials provided to students must be clear so that they can feel the benefits of this course. To know the reference, it is necessary to do a needs analysis so that students get the materials they need to support their learning process in the present or future (Febriyanti, 2018). The need analysis is a thing that is usually done for learning because every learner has a special need. In the informatics study program at the Institut Bisnis dan Informatika (IBI) Kosgoro 1957, one of the English courses taught in English for Computer and Technique. 
This course applies the material they learn; computer science. Where the focus of English being taught is computer-related. Based on observations in the informatics study program, especially in computer English learning, there are still many students who have difficulties in the learning process, Hence, in connection with this, this research aims to analyze the needs (necessities), deficiencies (lacks), and wants of the learners in the English for Computer and Technique course at the faculty of computer science.

Several studies on need analysis have been carried out previously. Sari (2019) has conducted research and the results of needs analysis concluded that students need English to understand texts and instructions along with to obtain information that is useful for their studies. Meanwhile Aflah and Rahmani (2018) concluded that need analysis shows that students need to have the ability to speak fluently and communicatively to prepare themselves to fulfill their professional demands. Septiana, Petrus, and Inderawati (2020), in their research concluded that the target needs are speaking and writing skills. The two language basic skills get a large portion in the preparation of the English syllabus. In addition, students need a learning process to focus more on practice than theory. Rifiyanti (2020) shows that it is important to use proper technology, quality, and instructors' competence to enhance and to encourage learners to engage in a learning environment.

\section{English for Computer and Technique}

English for Computer Science is a teaching approach to achieve the goals or competencies, students will master English in the computer field (Puspitasari, 2013). The teaching materials used are materials that can guide students to understand the basic concepts of English (English for Computer and Technique) in everyday life or under their study program. In computer science particularly programming, the language used to design, give instructions, or give orders is mostly English. This is the main correlation between English and computer science. It means the English do not serve as the communication language but also for having the ability to use the keywords and syntax used in giving commands to a computer.

\section{Need Analysis}

One of the basic assumptions of curriculum development is that a sound educational program should be based on an analysis of learners' needs. Procedures used to collect information about learners' needs are known as needs analysis (Richards, 2001). Need Analysis is the identification of language and skills used in determining and refining the content for the ESP course. It can also be used to assess learners and learning at the end of the course (Basturkmen, 2010). In conducting a need analysis, several basic components are needed to analyze the language needs of learners. The author in this research uses need analysis components derived from the theory of Hutchinson and Waters (1987) which consists of two components: target situation needs and learning needs. Target situation needs include "necessities", "lacks" and "wants". Learning needs, on the other hand, are how learners learn the language. 


\section{RESEARCH METHODOLOGY}

The research method is descriptive with a qualitative model. The descriptive method is used to describe and analyze target situation needs and learning needs of students in studying English for Computer and Technique courses. The research design is to explore respondents' responses to the components of the questions given in the questionnaire. The data is analyzed from the result provided in the questionnaire. The research design includes prepare a simple grid to to collate the data provided in the questionnaires, design a simple coding system, enter data on the grid, and calculate the proportion of respondents answering for each category of each question. The research is conducted at Institut Bisnis dan Informatika (IBI) Kosgoro 1957 with research participants selected from students of Informatics Study Program, Semester 2 because these students have finished the course of English for Computer and Technique in that semester. Technique data collection used in this study is a questionnaire. Data taken from the questionnaire consists of two components: target situation needs and learning needs. Target situation needs include necessities, lacks, and wants. Learning needs, on the other hand, are how learners learn the language (Hutchinson \& Waters, 1987).

\section{FINDINGS}

English for Computer and Technique is a subject given for informatics students at Institut Bisnis dan Informatika (IBI) Kosgoro 1957 in Semester 2. The topics taught include: what is the computer, inside a computer, how does computer work, input and output devices, computer: before vs after, internet, social networking, future trends and careers in computing, and grammar focus. In this section, the author explains the research results obtained from the answers to the questionnaires given to students after they have obtained the course. Questionnaires were given to 32 students. Questionnaires are given based on the components of the target situation needs and learning needs (Hutchinson \& Waters, 1987).

The survey started with questions about students' responses to their English listening, speaking, reading, and writing skills in English.

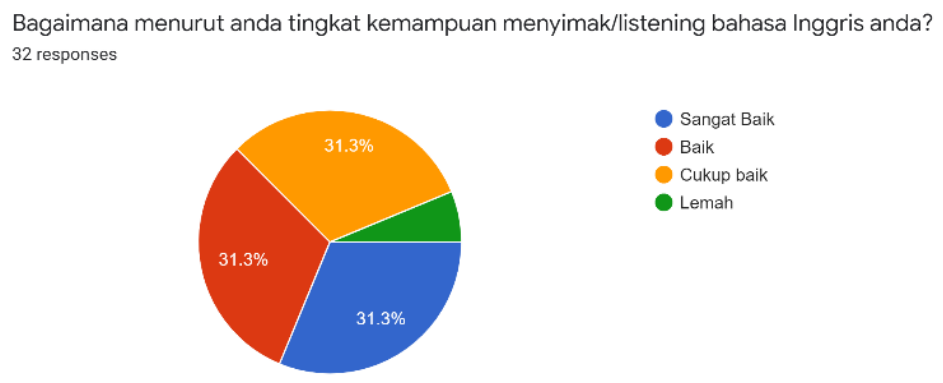

Figure 1. Listening Skills of the students

The questionnaire for Figure 1 is "What do you think about your English listening skill level?" And the responses shows that $31.3 \%$ of respondents chose very good, the response of good is $31.3 \%, 31.3 \%$ respondents chose fair, and $6.1 \%$ respondents chose poor. 
Bagaimana menurut anda tingkat kemampuan berbicara/speaking skill bahasa Inggris anda? 32 responses

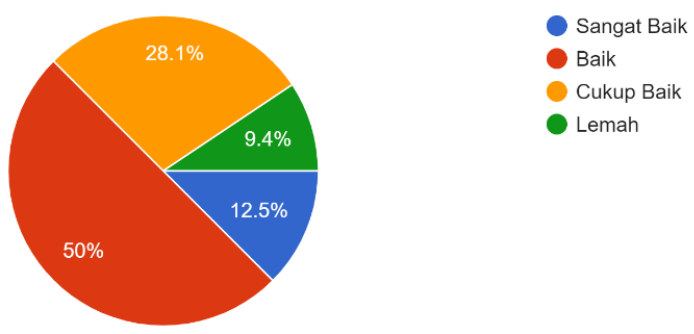

Figure 2. Speaking Skills of the students

The questionnaire for Figure 2 is "What do you think about your Englishspeaking skill level?" And the result shows that the response of very good is $12.5 \%$, the response of good is $50 \%$, the response of fair is $28.1 \%$, and the response of poor is $9.4 \%$.

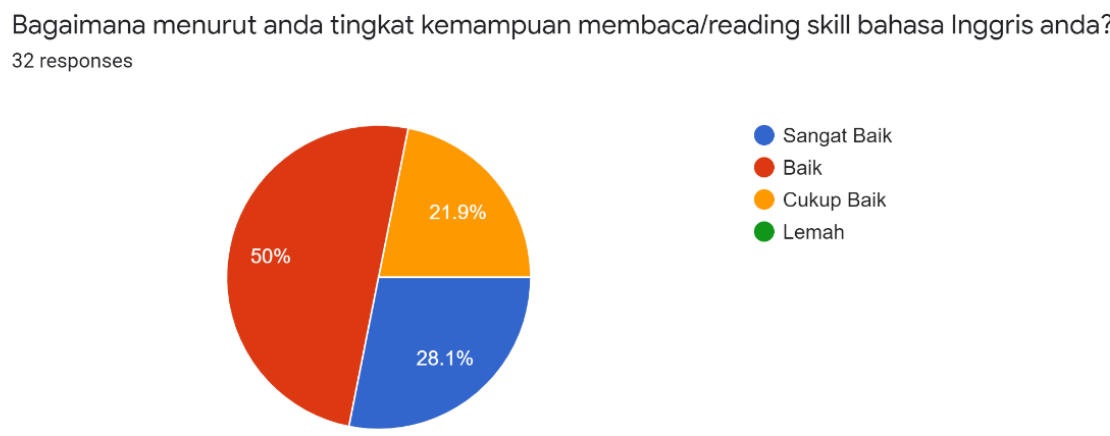

Figure 3. Reading Skills of the Students

The questionnaire for Figure 3 is "What do you think about your English reading skill level?" And the result shows that the percentage of response very good is $28.1 \%$, the percentage of response good is $50 \%$, and the per centage of response fair is $21.9 \%$.

Bagaimana menurut anda tingkat kemampuan menulis/writing skill bahasa Inggris anda?

32 responses

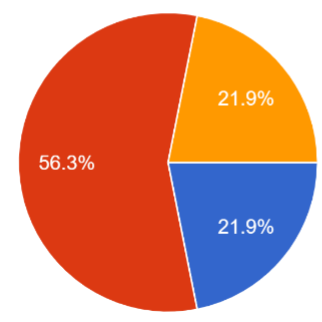

Sangat Baik

Figure 4. Writing Skills of the students 
The questionnaire for Figure 4 is "What do you think about your English reading skill level?" And the result shows that the percentage of response very good is $21.9 \%$, the percentage of response good is 56 , and the percentage of response fair is $21.9 \%$.
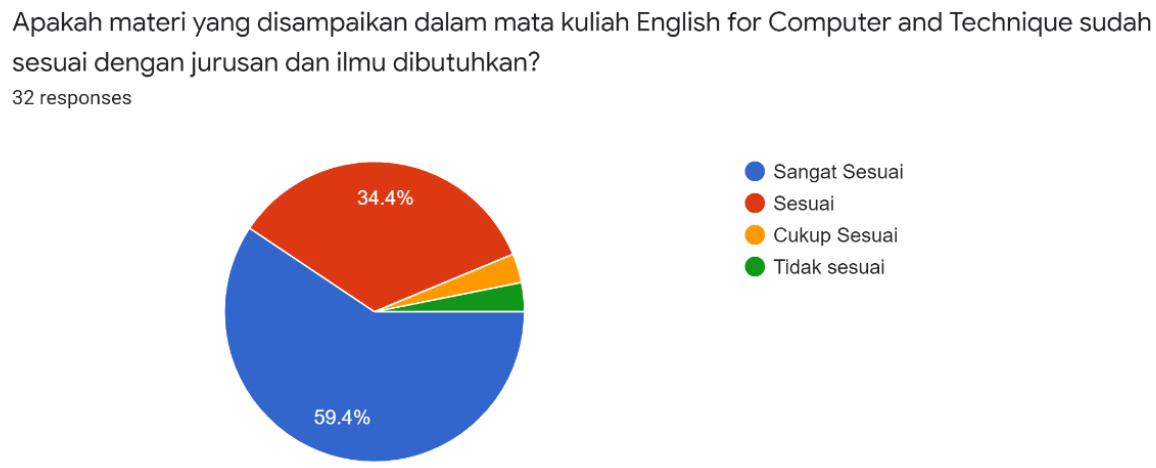

Figure 5. Correlated of the material with the study program

The questionnaire for Figure 5 is "Is the material presented in the English for Computer and Technique course appropriate with the required majors and knowledge?" And the result shows that the percentage of sangat sesuai (very appropriate) is $59,4 \%$, the percentage of sesuai (appropriate) is $34.4 \%$, the percentage of cukup sesuai (quite appropriate) is $3.1 \%$, and the percentage of tidak sesuai (inappropriate) is $3.1 \%$.

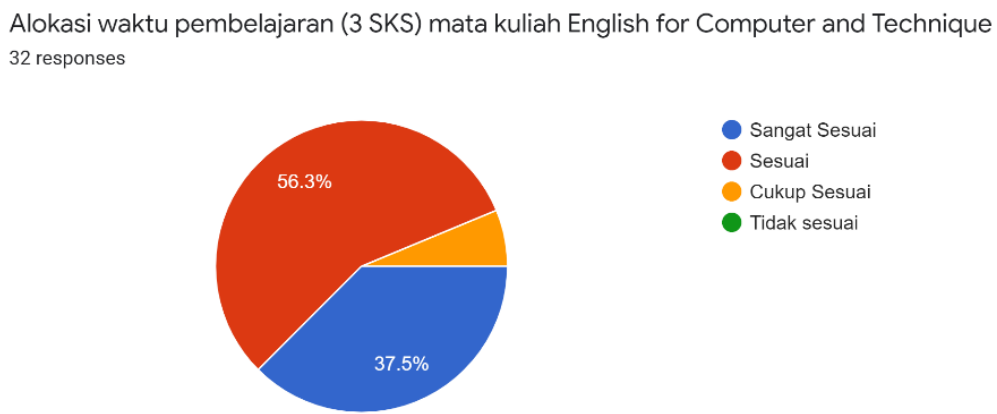

Figure 6. Time allocation of the course

The questionnaire for Figure 6 is about "Allocation of learning time ( 3 credits) for English for Computer and Technique course" And the result shows that the percentage of sangat sesuai (very appropriate) is $56,3 \%$, the percentage of sesuai (appropriate) is $37.5 \%$, and the percentage of cukup sesuai (quite appropriate) is $6.3 \%$.

The questionnaire for Figure 7 is "Is the role of the English for Computer and Technique course important for the field of science that you are engaged in?" And the result shows that the percentage of sangat sesuai (very appropriate) is $68,8 \%$, the percentage of sesuai (appropriate) is $28.1 \%$, and the percentage of cukup sesuai (quite appropriate) is $3.1 \%$. 


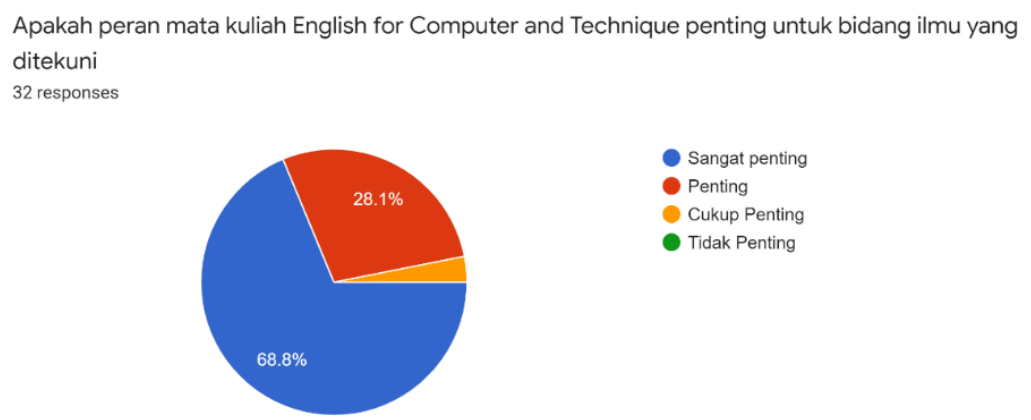

Figure 7. The role of English for Computer and Technique

The questionnaire for Figure 8 is "Focus on what language skills do you want to master and improve in the English for Computer and Technique course?" And the result shows that $78.1 \%$ of respondents want to master and improve their speaking skills, $15.6 \%$ of respondents want to master and improve their listening skills, $3.1 \%$ of respondents want reading skill, and 3.1 of respondents want writing skills.

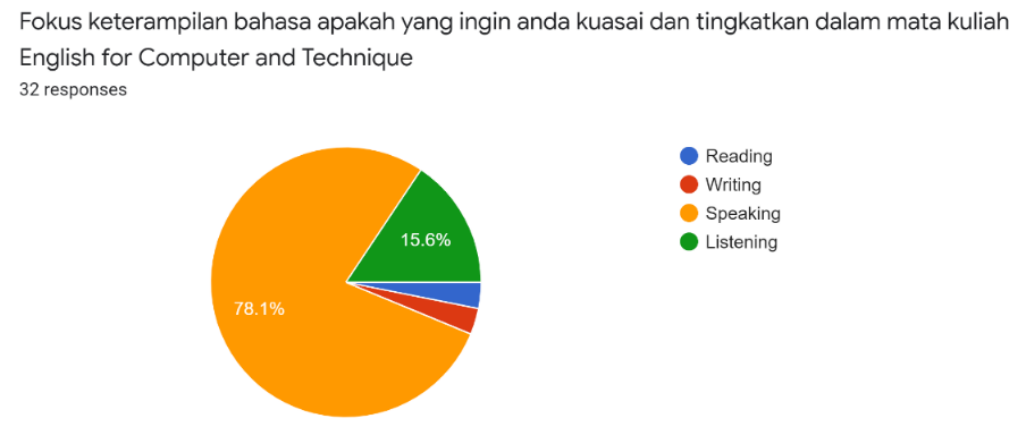

Figure 8. Language skill focus

The questionnaire for Figure 9 is "What activities do you like the most in the English for Computer and Technique course?" and the result shows that 59.4\% of respondents chose the speaking is the most favorite activity, $28.1 \%$ of respondents chose the reading is the most favorite activity, $9.4 \%$ of respondents chose the writing is the most favorite activity, and $3.1 \%$ of respondents choose the listening.

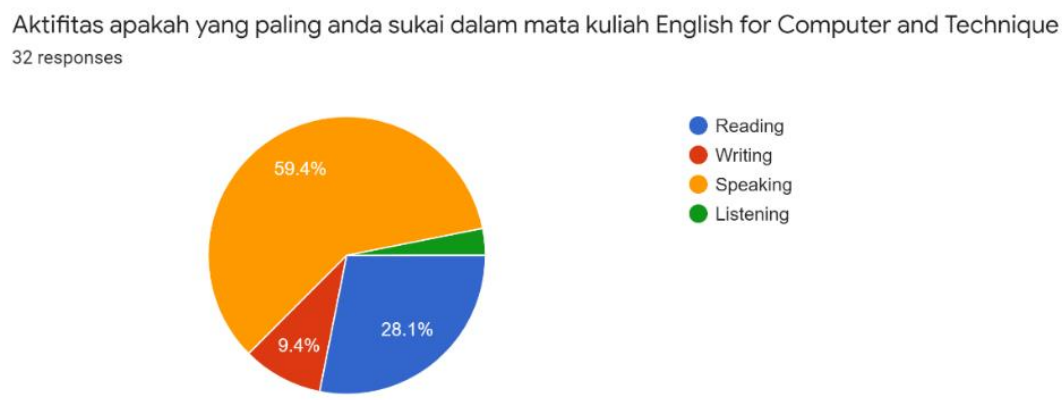

Figure 9. Most favorite activity 
The next questionnaire is about "What are the benefits of studying English for Computer and Technique courses for students majoring in computer science?" and the answers of respondents are as follows: to improve the speaking skill in English, to enhance the vocabulary of computer science in English, to ease in running programs and computer applications, useful for communicating in workplace, students more understand the language program in computer science.

The last questionnaire is about "What are your expectations as a student for the English for Computer and Technique course?" and the following are the responses: more practice of speaking are needed, fun learning method, ICT use in learning and teaching English as well as various of ICT application in English, and interesting textbooks.

\section{DISCUSSION}

\section{Target situation needs}

The analysis of target situation needs is in essence a matter of asking questions about the target situation and the attitudes towards that situation of the various participants in the learning process, which the components of the target situations needs are necessities, lacks, and wants (Hutchinson \& Waters, 1987). The result of the research regarding the necessities show that participants perceive the skills most needed is speaking skill, and the following is listening skill. They consider language speaking skill is a must-have skill to make it easier for them to get into the work environment. Mastery of speaking skills is one of the main factors that will make it easier for them to communicate. The need for speaking skills must be supported by the learning process, both in terms of material and the allocation of learning time. The results showed that most of the students considered English Computer and Technique course is appropriate for their expectations academically and work demands. This research is in line with Aflah and Rahmani (2018). The most answers to questions about the abilities or skills that are considered important in learning English is the ability to speak, which is $40 \%$. It shows that students know the needs of the job market, where almost all health companies put English language skills orally or in writing as a requirement in the recruitment of employees.

The data of need analysis for "lacks" shows that the language skills that are still a weakness of the participants are speaking skills and listening skills. This is as per the results of Diana and Mansur (2018) which states that speaking skills are the most difficult skills to master. The causes of difficulty in mastering speaking skills include lack of adequate vocabulary mastered by participants, difficulty memorizing, difficult pronunciation because there are so many differences between Indonesian and English, fear of making mistakes and being laughed at by friends, as well as lack of mastery of grammar. Hence, as a result of the need analysis of "wants" shows that the students want to achieve good command in English particularly speaking, listening, writing, and reading as well. They want English can make them easier to learn programming, useful to make programming software, and other computer science. In learning sessions, the students want to have more practice so that they often train their communication skills. This is also in line with research conducted by Setyowati (2019) the result indicates the respondents agree that learning all aspects of English is very important. 


\section{Learning Needs}

This type of needs analysis has to do with the strategies that learners employ to learn another language. Based on the findings what learners need to learn is speaking and listening skills as well as reading and writing. The development of learning methods for English for Computer and Technique materials is improved to achieve the targets and desires of the learners.

\section{CONCLUSIONS}

The results concluded that speaking and listening are the most needed skills from the learners, then followed by writing and reading. The English material that is appropriate with the field of science they are studying; computer science is in great demand and the students feel the benefits. English skills relevant to the field of computer science are very useful also for programming, coding, and all things computer-related. The desire of students to achieve good English skills is also very high, especially for the needs in the workplace. The results of this study are also expected to be material for improving the quality of learning, especially for English for Computer and Science courses so that they can achieve the goals and achievements desired by the institution as well as students.

\section{REFERENCE}

Aflah, M. N., \& Rahmani, E. F. (2018). Analisa Kebutuhan (Need Analysis) Mata Kuliah Bahasa Inggris untuk Mahasiswa Kejuruan. Jurnal Pendidikan Bahasa, 7(1), 77-89. http://dx.doi.org/10.31571/bahasa.v7i1.828

Basturkmen, H. (2010). Developing courses in English for specific purposes. Developing Courses in English for Specific Purposes. Palgrave Macmillan https://doi.org/10.1057/9780230290518

Diana, S., \& Mansur, M. (2018). Need Analysis on English Teaching Materials for ICT Students. ETERNAL (English, Teaching, Learning, and Research Journal), 4(2), 209-218. https://doi.org/10.24252/eternal.v42.2018.a6

Febriyanti, E. R. (2018). Identifikasi Analisis Kebutuhan Pembelajar Bahasa Inggris (Non Program Studi Bahasa Inggris) pada Mata Kuliah Bahasa Inggris ESP di Lingkungan FKIP Universitas Lambung Mangkurat Banjarmasin. Vidya Karya, 32(2), 123-138. https://doi.org/10.20527/jvk.v32i2.5230

Hutchinson, T., \& Waters, A. (1987). English for Specific Purposes. Cambridge University Press.

Puspitasari, I. (2013). English for Computer Science: Sebuah Analisis Kebutuhan Bahasa Inggris pada Mahasiswa Teknik Informatika. Jurnal Pro Bisnis, 6(1), 20-37.

Richards, J. C. (2001). Curriculum Development in Language Teaching. Cambridge University Press. https://doi.org/https://doi.org/10.1017/CBO9780511667220

Rifiyanti, H. (2020). Learners' Perceptions of Online English Learning during COVID-19 Pandemic. Scope : Journal of English Language Teaching, 5(1), 3135. https://doi.org/10.30998/scope.v5i1.6719

Sari, R. K. (2019). Analisis Kebutuhan Pembelajaran Bahasa Inggris pada Mahasiswa Kelas Karyawan. SAP (Susunan Artikel Pendidikan), 4(1), 38-45. 
https://doi.org/10.30998/sap.v4i1.3612

Septiana, I., Petrus, I., \& Inderawati, R. (2020). Needs analysis-based english syllabus for computer science students of bina darma university. English Review: Journal of English Education, 8(2), 299-310. https://doi.org/10.25134/erjee.v8i2.3027.Received

Setyowati, L. (2019). The Effectiveness of Good Interview For Students'motivation In Learning Speaking. JEELL (Journal of English Education, Linguistics and Literature) English Departement of STKIP PGRI Jombang,6(1), 11-20. https://doi.org/10.32682/jeell.v6i1.1052. 